\title{
KEPUASAN PENGGUNA APLIKASI E-PPGBM BERDASARKAN KUALITAS SISTEM MODEL KESUKSESAN DeLone -McLean
}

\author{
Masayu Meidiawani ${ }^{1}$, Misnaniarti ${ }^{2}$, Rizma Adlia Syakurah ${ }^{3}$ \\ Program Studi Magister Ilmu Kesehatan Masyarakat, Fakultas Kesehatan Masyarakat ${ }^{1,2,3}$ Univesitas \\ Sriwijaya, Indonesia \\ meidiawanimasayu@yahoo.com ${ }^{1}$, misnaniarti@ fkm.unsri.ac.id ${ }^{2}$
}

\begin{abstract}
Indonesia is still facing nutritional problems. The three burdens of malnutrition that exist today include undernutrition, hidden hunger and excess weight. This is the survival, development of children and the development of the nation. To overcome these nutritional problems, data on children under five is accurate, accurate, complete with names and addresses so that they can take appropriate action. This condition has prompted the Indonesian Ministry of Health to develop an information system for the application of the Community-Based Electronic Nutrition Reporting (e-CBNR) application. The researcher examines further the evaluation of the use of the e-CBNR application from the point of view of the application user with the DeLone and Mc.Lean Information System Success Model. The DeLone and Mc.Lean Information System Success Model is considered by many researchers because this information system success model is the most complete model. This study aims to analyze the relationship between system quality and user satisfaction in the Electronic Community-Based Nutrition Reporting (e-CBNR) Application. Cross-sectional analytic research with a quantitative approach. The research sample was all nutrition officers at Puskesmas Palembang who were placed on the e-CBNR application. Data collection was carried out inOctober 2020. The research instrument used a questionnaire with 51 respondents. Data analysis was performed univariate and bivariate using the Chi-Square test. The results showed that the quality of the system was good (54.9\%) and user satisfaction of the e-CBNR application was $66.7 \%$. Bivariate analysis shows that system quality is related to user satisfaction ( $p$-value $=0.004$ ). The Ministry of Health must make efforts to improve the quality of the system so that it can increase user satisfaction with the use of the e-CBNR application
\end{abstract}

Keywords $\quad$ : DeLone and McLean's Success Model, Nutritional status application

\begin{abstract}
ABSTRAK
Indonesia sampai saat ini masih menghadapi permasalahan gizi. Tiga beban malnutrisi yang dihadapi saat ini meliputi gizi kurang, kelaparan terselubung, dan berat badan berlebih. Hal ini mengancam kelangsungan hidup, tumbuh kembang anak, dan perkembangan bangsa. Untuk mengatasi permasalahan gizi tersebut diperlukan ketersediaan data anak balita yang akurat, lengkap dengan nama dan alamat sehingga dapat susun kebijakan intervensi yang tepat sasaran. Kondisi inilah yang mendrong Kementerian Kesehatan RI mengembangkan sistem informasi aplikasi Elektronik Pencatatan Pelaporan Gizi Berbasis Masyakarat (e-PPGBM). Peneliti mengkaji lebih jauh tentang evaluasi penggunaan aplikasi e-PPGBM dari sudut pengguna aplikasi dengan menggunakan Model Kesuksesan Sistem Informasi DeLone dan Mc.Lean. Model Kesuksesan Sistem Informasi DeLone dan Mc.Lean ini direkomendasikan oleh banyak peneliti karena model kesuksesan sistem informasi ini dianggap sebagai model yang paling komprehensif. Penelitian ini bertujuan untuk menganalisis hubungan kualitas sistem dengan kepuasan pengguna Aplikasi Elektronik Pencatatan Pelaporan Gizi Berbasis Masyarakat (ePPGBM). Penelitian analitik cross-sectional dengan pendekatan kuantitatif. Sampel penelitian seluruh petugas gizi Puskesmas kota Palembang yang mengelola Aplikasi e-PPGBM. Pengumpulan data dilakukan pada bulan Oktober 2020. Instrumen penelitian menggunakan kuesioner dengan responden 51 orang. Analisis data dilakukan secara univariat dan bivariat menggunakan uji Chi-Square. Hasil penelitian menunjukkan bahwa kualitas sistem baik (54,9\%) dan kepuasan pengguna Aplikasi ePPGBM sebesar $66,7 \%$. Analisa bivariat menunjukkan bahwa kualitas sistem berhubungan dengan kepuasan pengguna $(\mathrm{p}$-value $=0,004)$. Kementerian Kesehatan harus melakukan upaya peningkatan kualitas sistem sehingga dapat meningkatkan kepuasan pengguna pada penggunaan aplikasi e-PPGBM.
\end{abstract}

Kata kunci: Aplikasi Status Gizi, Model Kesuksesan Delone Dan Mclean 


\section{PENDAHULUAN}

Indonesia dan dunia hingga sekarang masih menghadapi masalah gizi, mulai dari balita hingga dewasa. Tiga beban malnutrisi yang dihadapi saat ini meliputi gizi kurang, kelaparan terselubung, dan berat badan berlebih. Hal ini mengancam kelangsungan hidup, tumbuh kembang anak, dan perkembangan bangsa. Sepertiga anak balita masih mengalami malnutrisi yaitu bertubuh pendek (stunting), bertubuh kurus (wasting), ataupun berat badan berlebih. Sementara dua pertiganya berisiko menderita malnutrisi dan kelaparan terselubung akibat asupan makan yang tidak berkualitas (Noorani, 2019).

Hasil Riskesdas 2018 hampir 3 dari 10 anak berusia di bawah lima tahun menderita stunting atau terlalu pendek untuk usia mereka, sedangkan 1 dari 10 kekurangan berat badan atau terlalu kurus untuk usia mereka dan seperlima anak usia Sekolah Dasar kelebihan berat badan atau obesitas (Kementerian Kesehatan RI, 2018).

Di Provinsi Sumatera Selatan angka malnutrisi masih cukup tinggi, bahkan melebihi angka nasional berdasarkan data Riskesdas 2018. Angka status gizi pendek dan sangat pendek di Sumatera Selatan mencapai 32\%, sementara angka status gizi pendek dan sangat pendek nasional 30,8\% untuk kategori anak balita. Sedangkan untuk kategori anak baduta tercatat $29,8 \%$, yang mana angka status gizi pendek dan sangat pendek nasional adalah 29,9\%. Selain itu prevalensi anak kurus $12,1 \%$ dan gemuk $11,8 \%$ di Propinsi Sumatera Selatan, dan tertinggi di Kota Palembang menunjukkan balita kurus sebesar $1,2 \%$ dan anak gemuk sebesar $1,4 \%$. Untuk angka balita gemuk bahkan Sumatera Selatan berada pada posisi Provinsi nomor dua tertinggi setelah Papua (Kementerian Kesehatan RI, 2018).

Besarnya komitmen Pemerintah Kota Palembang dalam hal ini Dinas Kesehatan kota Palembang untuk menurunkan angka malnutrisi juga dapat dilihat dari telah diterapkannya Permenkes No.14 tahun
2019 tentang Pelaksanaan Teknis Surveilans Gizi. Dalam Permenkes tersebut dijelaskan bahwa pelaksanaan surveilans gizi menggunakan sistem informasi gizi berbasis teknologi informasi yang disebut Sistem Informasi Gizi (Kementerian Kesehatan RI, 2019).

Pada Sigizi Terpadu terdapat modul elektronik Pencatatan Pelaporan Gizi Berbasis Msyarakat (e-PPGBM) yaitu modul yang digunakan untuk mencatat secara elektronik data individu sasaran lengkap dengan nama dan alamat yang bersumber dari Posyandu. Informasi hasil input data dapat menjadi bagian pelaporan Puskesmas kepada Dinas Kesehatan Kota Palembang.

Aplikasi e-PPGBM ini pertama kali diperkenalkan oleh Kementerian Kesehatan RI pada akhir tahun 2017. Pada tahun 2018 Dinas Kesehatan Provinsi Sumatera Selatan telah melakukan sosialisasi dengan seluruh Puskesmas di wilayah Provinsi Sumatera Selatan dengan narasumber dari Kementerian Kesehatan RI. Kegiatan sosialisasi itu bertujuan untuk meningkatkan pemahaman petugas dalam penggunaan aplikasi e-PPGBM. Sampai saat ini lebih kurang sudah tiga kali Dinas Kesehatan menyelenggarakan lagi pelatihan untuk penyegaran bagi petugas pengelola aplikasi e-PPGBM.

Sistem Informasi Kesehatan yang baik adalah sistem informasi yang mampu menghasilkan data/informasi yang akurat dan tepat waktu. Faktanya dalam hal manajemen kesehatan di tingkat kabupaten/kota, provinsi dan pusat, Sistem Informasi aplikasi e-PPGBM ini belum banyak berperan karena belum menghasilkan data/informasi yang akurat dan tepat waktu. Sampai dengan bulan Desember 2019 entry data balita pada aplikasi e-PPGBM di Kota Palembang baru mencapai $57,9 \%$. Hal ini berdampak pada tidak lengkapnya informasi status gizi sehingga menimbulkan ketidakakuratan dalam mengidentifikasi masalah gizi dan menghasilkan perumusan kebijakan yang 
salah dalam menangani permasalahan gizi di Kota Palembang khususnya dan di Indonesia pada umumnya.

Peneliti mengkaji lebih jauh tentang evaluasi penggunaan aplikasi e-PPGBM dari sudut pengguna aplikasi dengan menggunakan Model Kesuksesan Sistem Informasi DeLone dan Mc.Lean. Model Kesuksesan Sistem Informasi DeLone dan Mc.Lean ini paling banyak digunakan dan direkomendasikan oleh banyak peneliti karena model kesuksesan sistem informasi ini dianggap sebagai model yang paling komprehensif. Model kesuksesan sistem informasi ini mengevaluasi sistem informasi dari banyak sisi sehingga dapat memberikan kerangka evaluasi yang menyeluruh kepada peneliti dalam melihat kesuksesan suatu sistem informasi (DeLone \& McLean, 2003; Supriyatin et al., 2012).

Model Kesuksesan Sistem Informasi ini pertama kali diperkenalkan oleh DeLone dan Mc.Lean pada tahun 1992. Teori ini kemudian dikenal sebagai D\&M IS Success Model. Pada tahun 2003 teori ini mengalami penyempurnaan. Cara pengukuran kesuksesan penggunaan sistem informasi dalam teori ini dapat ditinjau melalui 6 dimensi yaitu kualitas sistem

Penelitian ini merupakan jenis penelitian analitik dengan pendekatan cross-sectional. Rancangan penelitian analitik cross sectional mempelajari hubungan antara variabel bebas dengan variabel terikat yang dilakukan sekali dalam waktu yang bersamaan. Pada setiap penelitian analitik selalu diawali dengan deskripsi data dengan mengacu pada ada tidaknya hubungan antar variabel. Oleh karena itu diperlukan hipotesis yang diformulasikan sebelum memulai penelitian (Sastroasmoro \& Ismael, 2011). Dari hasil pengukuran dapat dilihat prevalensi atau efek fenomena dari variabel

\section{HASIL}

\section{Analisi Univariat}

Analisis ini dilakukan untuk mengetahui distribusi frekuensi dan (system quality), kualitas informasi (information quality), kualitas pelayanan (service quality), penggunaan (use), kepuasan pengguna (user satisfaction), dan manfaat bersih (net benefit). Model ini cocok untuk digunakan sebagai model acuan dalam mengevaluasi sistem informasi (DeLone \& McLean, 2003).

Sampai saat ini belum ada penelitian mengenai evaluasi aplikasi e-PPGBM. Padahal ada begitu banyak manfaat dari pengembangan aplikasi e-PPGBM dan pentingnya ketersediaan keakuratan data informasi dari sistem informasi aplikasi tersebut. Selain itu aplikasi e-PPGBM dikembangkan oleh Kementerian Kesehatan sehingga otomatis wajib dijalankan di semua Puskesmas di seluruh Indonesia.

Oleh karena itu peneliti tertarik ingin mengkaji lebih jauh tentang evaluasi penggunaan aplikasi e-PPGBM dari sudut pengguna (petugas gizi Puskesmas). Hal ini dapat menjadi masukan untuk Kementerian Kesehatan dan Dinas Kesehatan dalam mengembangkan Sistem Informasi Aplikasi selanjutnya.

\section{METODE}

persentase dari variabel independen dan variabel dependen. Karakteristik dari responden berdasarkan jenis kelamin ditunjukkan berdasarkan tabel sebagai berikut :

\section{Tabel 1. Distribusi Frekuensi Karakteristik} Responden

\begin{tabular}{ccc}
\hline Indikator & \multicolumn{2}{c}{ Jumlah Responden } \\
\cline { 2 - 3 } & $\mathbf{n}$ & \% \\
\hline Jenis Kelamin & 1 & 2 \\
Laki-laki & 50 & 98 \\
Perempuan & & \\
Usia & 17 & 33,3 \\
20 - 30 Tahun & 22 & 43,1 \\
31 - 40 Tahun & 8 & 15,7 \\
41 - 50 Tahun & 4 & 7,8 \\
> 50 Tahun & & \\
Tingkat Pendidkan & 43 & 84,3 \\
Diploma & 8 & 15,7 \\
S1
\end{tabular}


Berdasarkan tabel 1 diketahui bahwa sebagian besar responden penelitian ini adalah perempuan yaitu sebesar $98 \%$ dan berusia 31-40 tahun sebesar $43,1 \%$.

\section{Variabel Kualitas sistem}

Hasil penelitian Model Kesuksesan

DeLone-McLean meliputi variabel kualitas sistem didapatkan dari skor 9 pernyataan indikator variabel tersebut. Jumlah skor

Berdasarkan tabel 2 menunjukkan bahwa hasil penelitian dari variabel kualitas sistem, terdapat $54,9 \%$ responden yang menyatakan kualitas sistem Aplikasi ePPGBM baik.

Tabel 3. Distribusi Responden Berdasarkan Kepuasan Pengguna

\begin{tabular}{lcc}
\hline $\begin{array}{c}\text { Variabel } \\
\text { Kepuasan Pengguna }\end{array}$ & n & \% \\
\hline Puas & 34 & 66,7 \\
Tidak Puas & 17 & 33,3 \\
\hline
\end{tabular}

Berdasarkan tabel 3 diketahui bahwa sebagian besar responden puas dengan Aplikasi e-PPGBM yaitu sebesar 66,7\%. dikelompokkan menjadi dua yaitu baik dan kurang baik, dapat dilihat pada tabel 2 sebagai berikut :

Tabel 2. Distribusi Frekuensi Responden Berdasarkan Kualitas Sistem

\begin{tabular}{lcc}
\hline $\begin{array}{c}\text { Variabel Kualitas } \\
\text { Sistem }\end{array}$ & n & \% \\
\hline Baik & 28 & 54,9 \\
Kurang Baik & 23 & 45,1 \\
\hline
\end{tabular}

\section{Kepuasan Pengguna}

Hasil penelitian pada variabel kepuasan pengguna dikelompokkan menjadi dua yaitu puas dan tidak puas, dapat dilihat pada tabel sebagai berikut :

\section{Hubungan Kualitas Sistem dengan Kepuasan Pengguna Aplikasi e-PPGBM}

Variabel Kualitas Sistem diuji hubungannya dengan Kepuasan Pengguna pada Puskesmas di Kota Palembang dengan menggunakan uji Chi-Square pada tingkat kemaknaan $95 \%$ atau $\alpha=0,05$.

Dapat dilihat sebagai berikut :

Tabel 4. Hubungan Variabel Kualitas Sistem dengan Kepuasan Pengguna Aplikasi e-PPGBM

\begin{tabular}{|c|c|c|c|c|c|c|c|c|}
\hline \multirow{3}{*}{$\begin{array}{l}\text { Kualitas } \\
\text { Sistem }\end{array}$} & \multicolumn{4}{|c|}{ Kepuasan Pengguna } & \multirow{2}{*}{\multicolumn{2}{|c|}{ Total }} & \multirow{3}{*}{$\begin{array}{l}p- \\
\text { value }\end{array}$} & \multirow{3}{*}{ PR $(95 \%$ CI $)$} \\
\hline & \multicolumn{2}{|c|}{ Tidak Puas } & \multicolumn{2}{|c|}{ Puas } & & & & \\
\hline & $\mathrm{n}$ & $\%$ & $\mathrm{n}$ & $\%$ & $\mathrm{n}$ & $\%$ & & \\
\hline $\begin{array}{l}\text { Kurang } \\
\text { Baik }\end{array}$ & 13 & 56,5 & 10 & 43,5 & 23 & 100 & 0,004 & $\begin{array}{l}7,800 \\
(95 \% \text { CI 2,039 - }\end{array}$ \\
\hline Baik & 4 & 14,3 & 24 & 85,7 & 28 & 100 & & $29,838)$ \\
\hline Total & 17 & 33,3 & 34 & 66,7 & 51 & 100 & & \\
\hline
\end{tabular}

Berdasarkan tabel 4 menunjukkan bahwa variabel kualitas sistem $p$-value $=0,004$ dengan kepuasan pengguna adalah signifikan.

\section{PEMBAHASAN}

\section{Kualitas Sistem dengan Kepuasan Pengguna}

Penerimaan hipotesis ini menyatakan bahwa kualitas sistem berpengaruh terhadap kepuasan pengguna sistem Aplikasi Elektronik Pencatatan Pelaporan Gizi Berbasis Masyarakat. Meng indikasikan bahwa kualitas sistem rendah akan mempengaruhi rendahnya tingkat kepuasan pengguna. Berdasarkan teori DeLone \& Mc.Lean pada tahun 1992, kualitas sistem merupakan ukuran yang bisa menentukan keberhasilan suatu sistem sedemikian rupa sehingga jika pengguna menikmati efisensi operasionalnya suatu sistem, maka pengguna akan merasa puas 
dengan sistem tersebut (DeLone \& McLean, 1992).

Kualitas sistem merupakan perpaduan dari kualitas hard ware dan software (Budiyanto, 2009). Kepuasan pengguna terhadap suatu sistem informasi didefinisikan sebagai pandangan pengguna terhadap suatu sistem informasi secara nyata, tidak hanya pada teknik suatu kualitas sistem (Guimaraes et al., 2003). Bailey \& Pearson (1983) menemukan bahwa semakin tinggi penilaian pengguna terhadap kualitas suatu sistem, maka akan meningkatkan kepuasan mereka terhadap sistem tersebut. Jika kualitas sistem tidak baik maka pengguna akan merasa tidak nyaman menggunakan sistem Aplikasi ePPGBM yang akan mengakibatkan pengguna tidak puas terhadap Aplikasi tersebut.

Hasil analisis secara bivariat yang telah dibahas sebelumnya, bahwa terdapat hubungan yang signifikan antara kualitas sistem dengan kepuasan pengguna pada aplikasi ini dengan $p$-value $=0,004$ dan OR $=7,800$.

Hal ini berbeda dengan hasil penelitian yang dilakukan oleh Handayani, dkk di mana indikator variabel lain yang berperan lebih besar selain dukungan cepat dan efisien, kemudahan memantau aktivitas akses mudah dimana saja, dan kemudahan tampilan pengguna. Hal ini dapat dijelaskan karena kedua penelitian ini memiliki objek penelitian yang berbeda, dimana penelitian ini meneliti tentang aplikasi yang berguna untuk membantu responden dalam melakukan pekerjaan dalam hal ini pelaporan program, sedangkan penelitian Critical Success Factors for implementation JKN in Indonesia oleh Handayani dkk memiliki objek penelitian berupa masyarakat umum yang menggunakan aplikasi mobile JKN.

Hasil penelitian ini tidak sejalan dengan hasil penelitian yang dilakukan di Yunani dengan judul Measuring the success of the Greek Taxation Information System. Penelitian yang dilakukan oleh Jordan Floropoulos, dkk pada tahun 2010 ini melakukan penelitian mengenai hubungan antara kualitas sistem, kualitas informasi, dan kualitas layanan terhadap kepuasan pengguna pada sistem informasi pajak (E TAXIS) di Yunani. Hasil penelitian menunjukkan hubungan yang kuat untuk setiap variabel terhadap kepuasan pengguna yaitu kualitas informasi dan kualitas layanan, kecuali kualitas sistem (Floropoulos et al., 2010).

Penelitian terdahulu lainnya yang tidak sejalan yaitu penelitian yang dilakukan oleh Irwin Brown \& Ruwangga Jayakody, 2008 yang berjudul B2C e-Commerce Success: a Test and Validation of a Revised Conceptual Model pada tahun 2008, menemukan bahwa tidak adanya hubungan yang signifikan varibel kualitas sistem dengan kepuasan pengguna dan terjadi karena menurut Rai et al (1992) dan Seddon (1997), kualitas sistem sering diasumsikan sebagai kemudahan atau kesulitan penggunaan sistem (Brown \& Jayakody, 2008). Begitu juga degan hasil penelitian Wona Choi dkk pada tahun 2013 dengan judul Information System Success Model for Customer Relationship Management System in Health Promotion Centers yang membuktikan hubungan yang tidak signifikan antara kualitas sistem dan kepuasan pengguna (Choi et al., 2013)

Kualitas sistem yang disediakan Aplikasi e-PPGBM mempunyai pengaruh terhadap kepuasan pengguna. Kementerian Kesehatan harus meningkatkan dan memperbaiki kualitas sistem dari Aplikasi e-PPGBM. Diharapkan dengan meningkatkan dan memperbaiki kualitas sistem aplikasi ini, akan meningkatkan kepuasan pengguna dalam menggunakan Aplikasi e-PPGBM dan meningkatkan frekuensi penggunaan sistem tersebut.

\section{KESIMPULAN}

Hasil penelitian menunjukkan bahwa hubungan antara kualitas sistem $p$ value $=$ 
$0,004<0,05$ terhadap kepuasan pengguna Aplikasi e-PPGBM adalah signifikan. Kekuatan pada kualitas sistem aplikasi ePPGBM ini adalah kemudahan dalam mempelajari sistem, sedangkan kelemahannya adalah waktu tunggu (respone time) yang lama, sulit diakses pada jam sibuk / pada saat banyak petugas yang mengakses aplikasi ini, output aplikasi ini belum dapat digunakan untuk mengambil keputusan karena entry data pengukuran belum mencapai $100 \%$.

\section{UCAPAN TERIMAKASIH}

Terimakasih kepada semua pihak yang telah terlibat dalam penelitian ini. Terimakasih juga kepada semua responden yang telah memberikan ilmunya sehingga selesainya penelitian ini.

\section{DAFTAR PUSTAKA}

Bailey, J. E., \& Pearson, S. W. (1983). Development Of A Tool For Measuring And Analyzing Computer User Satisfaction. Management Science, 29(5), 530-545.

Brown, I., \& Jayakody, R. (2008). B2C eCommerce Success: a Test and Validation of a Revised Conceptual Model. The Electronic Journal Information Systems Evaluation, 11(3), 167-184.

Budiyanto. (2009). Evaluasi Kesuksesan Sistem Informasi Dengan Pendekatan Model DeLone Dan McLean ( Studi Kasus Implementasi Billing System Di RSUD Kabupaten Sragen ). In Program Studi Magister Akuntansi. Universitas Sebelas Maret Surakarta.

Choi, W., Rho, M. J., Park, J., Kim, K. J., Kwon, Y. D., \& Choi, I. Y. (2013). Information System Success Model for Customer Relationship Management System in Health Promotion Centers. Healthcare Informatics Research, 19(2), 110-
120.

https://doi.org/10.4258/hir.2013.19.2. 110

DeLone, W. H., \& McLean, E. R. (2003). The DeLone and McLean Model of Information Systems Success: A TenYear Update. Journal of Management Information Systems, 19(4), 9-30. https://doi.org/10.1016/j.giq.2003.08. 002

Floropoulos, J., Spathis, C., Halvatzis, D., \& Tsipouridou, M. (2010). Measuring the success of the Greek Taxation Information System. International Journal of Information Management, $30(1)$, $47-56$. https://doi.org/10.1016/j.ijinfomgt.20 09.03.013

Guimaraes, T., Staples, D. S., \& Mckeen, J. D. (2003). Empirically Testing Some Main User-Related Factors for Systems Development Quality. Quality Management Journal, 10(4), 39-50.

https://doi.org/10.1080/10686967.200 3.11919083

Kementerian Kesehatan RI. (2018). Hasil Utama Riset Kesehatan Dasar (RISKESDAS). Badan Penelitian Dan Pengembangan Kesehatan, 1220. https://doi.org/10.1088/17518113/44/8/085201

Kementerian Kesehatan RI. (2019). Peraturan Menteri Kesehatan Republik Indonesia Nomor 14 Tahun 2019 Tentang Pelaksanaan Teknis Surveilans Gizi (p. 81). Kementrian Kesehatan RI.

Noorani. (2019). Status Anak Dunia 2019 | UNICEF Indonesia. In UNICEF. UNICEF Indonesia. https://www.unicef.org/indonesia/id/s tatus-anak-dunia-2019

Sastroasmoro, S., \& Ismael, S. (2011). Dasar-dasar Metodologi Penelitian Klinis (4th ed.). Sagung Seto. 
Supriyatin, Sasmito, E., \& Sulistyowati, E. E. (2012). Evaluasi Pengaruh Sistem Informasi Manajemen (SIM) Terhadap Kepuasan Pengguna di Instalasi Farmasi RS " $X$ " di Cirebon dengan Model DeLone \& McLean. Jurnal Farmasi Indonesia, 9(1), 2329.

https://doi.org/10.31001/JFI.V9I1.719 